\section{Sonografische Diagnose von Phäochromozytomen im Kindes- und Jugendalter}

\section{Einführung \\ $\nabla$}

Phäochromozytome entstehen aus den chromaffinen Zellen des Nebenierenmarks oder des thorakalen und abdominalen Grenzstrangs (Paraganglien). Es handelt sich um neuroendokrine Tumoren, die meist Katecholamine (Adrenalin, Noradrenalin), selten auch andere Hormone produzieren. Maligne Phäochromozytome bilden auch Dopamin. Mit Ausnahme des Vorkommens im

\section{Sonographic Diagnosis of Pheochromocytoma in Childhood and Adolescence}

\section{Introduction}

Pheochromocytomas arise from chromaffin cells of the adrenal medulla or the thoracic and abdominal sympathetic trunk (paraganglia). These neuroendocrine tumors mostly produce catecholamines (adrenaline, noradrenaline) and rarely other hormones. Malignant pheochromocytomas also discharge dopamine. With the exception of the presence within hereditary syndromes, the



Abb. 1 a Sonografischer Oberbauchquerschnitt: Darstellung dreier retroperitonealer Tumoren. Scharf begrenzte echoarme Raumforderungen mit homogener Echotextur im Bereich des linken Nierengefäßstiels, rechts paraaortal sowie retrocaval rechts. b MRT Oberbauch (Patient 1): Raumforderung im Bereich des rechten Nierengefäßstiels, retrocaval sowie rechts paraaortal. c MIBG-Szintigramm: Signalanreicherung des Radionuklids Jod-123-MIBG im Bereich der sonografisch und MRT-tomografisch bekannten Tumoren. Kein Anhalt für Metastasen. d Sonografischer Oberbauchlängsschnitt durch das rechte Abdomen. Ovaläre, scharf begrenzte echoarme Raumforderung im Bereich des rechten oberen Nierenpols (Marker).

Fig. 1 a Upper abdominal sonographic cross section showing three retroperitoneal tumors. Sharply circumscribed hypoechoic masses with homogeneous echo texture in the region of the left renal vascular pedicle, the right para-aortic and right retrocaval region. b Upper abdominal MRI: mass near the right renal vascular pedicle and in the right para-aortic and retrocaval region. c MIBG scintigraphy: signal enhancement of radionuclide iodine-123-MIBG in the region of tumors known from ultrasound and MRI. No evidence of metastasis. $d$ Upper abdominal sonografic longitudinal section through the right abdomen: ovoid, sharply defined hypoechoic mass in the right upper pole of the kidney (markers). 
Rahmen hereditärer Syndrome sind ätiologische Faktoren nicht bekannt. Wir berichten von 3 männlichen Jugendlichen, die mit Erstmanifestationen eines Phäochromozytoms aufgefallen sind.

\section{Fall I}

$\nabla$

Anamnese: Ein 14 Jahre alter Jugendlicher wurde zur Abklärung asthmatischer Beschwerden vorgestellt. Er beklagte seit Monaten eine eingeschränkte Leistungsfähigkeit mit rezidivierendem Husten bei körperlicher Belastung. Er gab an, in den letzten 6 Monaten ungewollt $5 \mathrm{~kg}$ Körpergewicht abgenommen zu haben. $\mathrm{Zu}-$ sätzlich traten Schweißausbrüche und Herzrasen auf. In der Familienanamnese fand sich ein Phäochromozytom beim Vater. Befund: Blutdruck bei Aufnahme 150/100 mmHg, Herzfrequenz 136/min. Der restliche körperliche Untersuchungsbefund war unauffällig.

Zusatzuntersuchungen: Die 24-Stunden-Langzeitblutdruckmessung bestätigte die arterielle Hypertonie mit tachykarder Herzaktion bei aufgehobener Tag-Nachtabsenkung. Die sonografische Untersuchung zeigte eine Raumforderung von $5 \times 4 \mathrm{~cm}$ im Bereich der rechten und einen Tumor der linken Nebenniere (○ Abb.1). Zusätzlich stellte sich eine retroperitoneal gelegene Raumforderung dar, die die Vena cava von dorsal imprimierte. Die Vanilinmandelsäure (VMS) war im Plasma mit 75.5 $\mu \mathrm{g} / 1$ und im Urin mit $26.2 \mathrm{mmol} / \mathrm{mol}$ Kreatinin deutlich erhöht. Im MRT zeigten sich beidseitige Nebennierentumoren. Die Metajodbenzylguanidin (MIBG)-Sequenz-Szintigrafie wies eine positive Aktivität für Jod 123 in den vorbeschriebenen Raumforderungen nach. Anhalte für Metastasen ergaben sich nicht.

\section{Fall II}

Ein 16 Jahre alter Jugendlicher wurde aufgrund einer akuten Cholezystitis stationär eingewiesen. Bei Aufnahme fielen erhöhte Blutdruckwerte (165/90 mmHg), eine Tachykardie (110/min) und eine Hyperhidrosis auf. Sonografisch konnte eine $6 \times 5 \mathrm{~cm}$ große solide Raumforderung mit einzelnen Zysten am rechten oberen Nierenpol nachgewiesen werden ( $\bullet$ Abb. 2). Noradrenalin im Plasma (1950 mg/l) war deutlich erhöht. MRT und MIBGSzintigramm untermauerten den Verdacht eines Phäochromozytoms.

\section{Fall III}

Ein 12 Jahre alter Junge wurde mit Verdacht auf EBV-Infektion vorgestellt. Er klagte seit Monaten über Abgeschlagenheit, Tachykardie und Hyperhidrosis. Ambulant waren erhöhte Transaminasen sowie erhöhte Entzündungsparameter aufgefallen. Sonografisch fanden sich ein Tumor am Nierengefäßstiel links sowie eine $5 \times 4,5 \mathrm{~cm}$ große Raumforderung am rechten oberen Nierenpol (ه Abb.3). Die 24-Stunden-Langzeitblutdruckmessung zeigte eine arterielle Hypertonie ohne Tag-Nacht-Absenkung. Chromogranin A (CGA) im Serum und VMS im Plasma und Urin waren erhöht. MRT und MIBG-Szintigrafie ergaben den Verdacht eines beidseitigen Phäochromozytoms. etiological factors are unknown. We report on three male adolescents who presented with pheochromocytomas.

\section{Case I}

$\nabla$

Anamnesis: A 14-year-old adolescent was presented for the evaluation of asthmatic symptoms. For months he complained of limited performance with a recurrent cough during exercise. He claimed to have unintentionally lost $5 \mathrm{~kg}$ of body weight in the last 6 months. Additional symptoms were sweating and palpitations. The family history revealed that the patient's father had a pheochromocytoma. Findings: Blood pressure at admission $150 / 100 \mathrm{mmHg}$, heart rate $136 / \mathrm{min}$. The rest of the physical examination was unremarkable.

Additional investigations: 24-hour blood pressure measurement confirmed arterial hypertension with elevated heart rate and failing difference of the blood pressure between day and night. In addition, there was a retroperitoneal mass pressing dorsally against the vena cava. The vanillylmandelic acid (VMS) was significantly increased in plasma with $75.5 \mathrm{~g} / \mathrm{l}$ and in urine with $26.2 \mathrm{mmol} / \mathrm{mol}$ creatinine. MRI showed bilateral adrenal tumors. The metajodbenzylguanidin (MIBG) scintigraphy showed a positive activity for iodine 123 in these lesions. There was no evidence for metastases. ( $\bullet$ Fig. 1)

\section{Case II}

$\nabla$

A 16-year-old teenager was admitted to our hospital due to acute cholecystitis. At admission, increased blood pressure (165/90 mmHg), a tachycardia (110/min), and hyperhidrosis were noticed. Sonography detected a solid mass measuring $6 \times 5 \mathrm{~cm}$ with single cysts in the right upper pole of the kidney (० Fig. 2). Plasma norepinephrine $(1950 \mathrm{mg} / \mathrm{l})$ was significantly

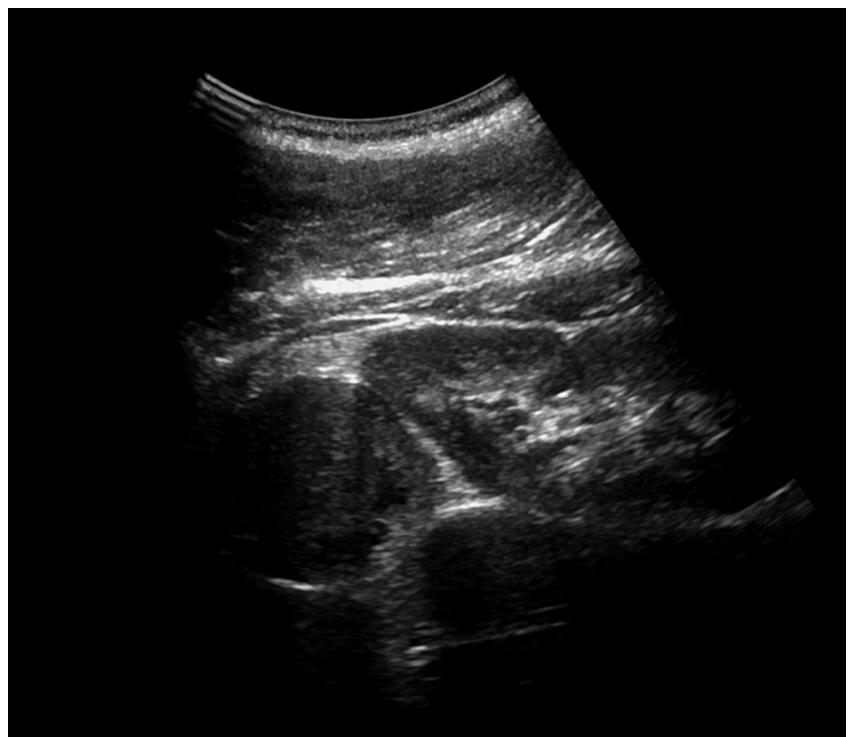

Abb. 2 Längsschnitt durch den rechten oberen Nierenpol von dorsal: echoarme, gut abgrenzbare Raumforderung am oberen Nierenpol. Keine Verkalkungen.

Fig. 2 Longitudinal section through the right upper pole of the kidney from the dorsal side: hypoechoic, well-circumscribed lesion at the upper pole of the kidney. No calcifications. 


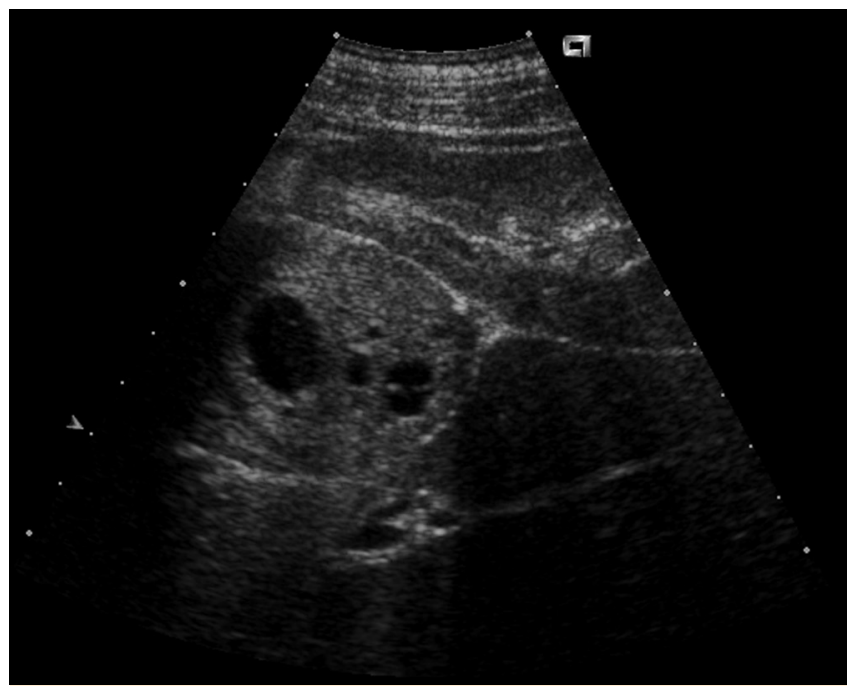

Abb. 3 Längsschnitt durch den oberen rechten Nierenpol von dorsal. Gut abgrenzbare Raumforderung mit echoarmem, leberähnlichem innenreflexmuster mit einzelnen zystischen Arealen ohne Verkalkungen.

Fig. 3 Longitudinal section through the upper right renal pole. Well-circumscribed mass with hypoechoic, liver-like internal reflection patterns with individual cystic areas without calcifications.

Die Tumoren aller drei Patienten wurden unter medikamentöser Alphablockade operativ in toto entfernt. Histologisch bestätigte sich jeweils die Diagnose eines Phäochromozytoms. Eine maligne Entartung lag nicht vor. Die molekulargenetische Untersuchung konnte bei Patient 1 und 3 eine Mutation auf dem von HippelLindau-Gen nachweisen.

\section{Diskussion}

$\nabla$

Die Inzidenz von Phäochromozytomen liegt bei etwa 0,4/100000 pro Jahr, 10\% der Fälle kommen bei Kindern und Jugendlichen vor. Das durchschnittliche Erkrankungsalter liegt bei 40-50 Jahren, bei den hereditären Formen kann die Erkrankung früher auftreten. Leitsypmtom der klinischen Manifestation ist die arterielle Hypertonie. Im Gegensatz zum Erwachsenenalter, in dem meist eine paroxysmale Hypertonie mit Blutdruckkrisen das klinische Erscheinungsbild bestimmen, weisen 50\% der Kinder bei Diagnosestellung eine persistierende Hypertonie auf. Typischerweise stellt sich in der 24-Stunden-Langzeitblutdruckmessung eine arterielle Hypertonie mit Tachykardie und fehlender TagNachtabsenkung dar. Begleitsymptome sind Kopfschmerzen, Schwitzen, blasse Haut und Herzklopfen. Ein Gewichtsverlust kann aufgrund des Hypermetabolismus vorliegen. Bei verdächtiger Klinik sollte eine Quantifizierung der Katecholamine (Adrenalin und Noradrenalin sowie der Katecholaminaabbauprodukte Homovanilinsäure, Vanillinmandelsäure) im Plasma und Urin erfolgen. Werte über $200 \mathrm{ng} / \mathrm{dl}$ für Gesamtkatecholamine im Urin gelten als pathologisch, Werte kleiner $50 \mathrm{ng} / \mathrm{dl}$ als normal.

Bildgebendes Verfahren der ersten Wahl ist die Sonografie des Abdomens. Verdächtig sind scharf begrenzte Raumforderungen mit weitgehend homogener Echotextur sowie einzelnen zystischen Anteilen (K. Müssig et al, Fortschr Röntgenstr 2011; 183(11): 995-1000). Verkalkungen, die charakteristisch für Neuroblastome sind, werden nicht gefunden (KH Deeg et al, Ultraschall in Med. 2007;28(3): 313-320). Die Tumoren sind meist im Bereich der Nebennierenlogen sowie eventuell paravertebral increased. MRI and MIBG scintigraphy confirmed the strong suspicion of a pheochromocytoma.

\section{Case III \\ $\nabla$}

A 12-year-old boy presented with suspected EBV infection. He had been complaining for months about fatigue, tachycardia, and hyperhidrosis. Elevated serum transaminases and inflammatory parameters were noticed. Ultrasonography showed a tumor in the left renal vascular pedicle and a $5 \times 4.5 \mathrm{~cm}$ mass in the right upper pole of the kidney ( $\bullet$ Fig. 3). 24-hour blood pressure measurement showed arterial hypertension without any difference between day and night. Chromogranin A (CGA) in serum and VMS in plasma and urine were increased. MRI and MIBG scintigraphy revealed a suspected bilateral pheochromocytoma.

The tumors in all three patients were completely removed surgically under alpha blockade. Histological examination confirmed the diagnosis of pheochromocytoma. Malignant degeneration was not present. The molecular genetic analysis detected a mutation in the "von Hippel-Lindau gene" in patients 1 and 3.

\section{Discussion}

$\nabla$

The incidence of pheochromocytomas is about $0.4 / 100,000$ per year. Only $10 \%$ of cases occur in children and adolescents. The average age at diagnosis is $40-50$ years. Hereditary forms of the disease can occur earlier. The hallmark of the clinical manifestation is arterial hypertension and tachycardia. In contrast to adults, where paroxysmal hypertension with blood pressure crises is the most dominating clinic symptom, only $50 \%$ of children show persistent hypertension when a pheochromocytoma is diagnosed. Typically, the 24-hour blood pressure recording shows arterial hypertension with tachycardia and a lack of day and night differentiation. Accompanying symptoms include headache, sweating, pale skin, and heart palpitations. Weight loss may be due to hypermetabolism. If there is suspicion of a pheochromocytoma, serum levels of catecholamines and their metabolites (epinephrine and norepinephrine as well as homovanillyl acid, vanillylmandelic acid) should be quantified in plasma and urine. Values above $200 \mathrm{ng} / \mathrm{dl}$ for catecholamine excretion in urine are considered pathologic, and values less than $50 \mathrm{ng} / \mathrm{dl}$ are normal. Sonography of the abdomen is the first imaging method that should be used. Suspicious lesions are sharply demarcated with a largely homogeneous echo texture as well as individual cystic components (K. Muessig et al., Fortschr Röntgenstr 2011; 183 (11): 995-1000). Calcifications, which are characteristic of a neuroblastoma, are not found (KH Deeg et al., Ultraschall Med. 2007; 28(3): 313-320). The tumors often arise from the adrenal glands and eventually from the paravertebral sympathetic chain. The main differential diagnosis is neuroblastoma. In contrast to pheochromocytomas, neuroblastomas are less distinguishable from the surrounding area. They are characterized by inhomogeneous internal echoes with calcifications in 2/3 of all cases (KH Deeg et al. Monatschrift Kinderheild 1992; 140 (5): 286-295). If one or more pheochromocytomas are suspected, MRI and MIBG scintigraphy should be performed. The tracer iodine-123 MIBG accumulates in catechoamine-producing tissues and causes corresponding signal enhancement. MIBG scintigraphy has a specific role in detecting extra-adrenal pheochromocytomas and their 
entlang des sympathischen Grenzstrangs lokalisiert. Die wichtigste Differentialdiagnose ist das Neuroblastom. Im Gegensatz zu Phäochromozytomen sind Neuroblastome schlechter von der Umgebung abgrenzbar. Sie haben ein inhomogenes Binnenreflexmuster und weisen in 2/3 aller Fälle Verkalkungen auf ( $\mathrm{KH}$ Deeg et al. Monatschrift Kinderheild. 1992; 140(5): 286-295). Bei fortbestehendem Verdacht auf ein oder mehrere Phäochromozytome sollte eine MRT-Untersuchung und eine MIBG-Sequenzszintigrafie durchgeführt werden. Hierbei reichert sich der Tracer 123-Jod MIBG in katecholaminproduzierenden Gewebe an und führt zu einer entsprechenden Signalanreicherung. Der MIBGSzintigrafie kommt eine besondere Rolle beim Ausschluss oder Nachweis extraadrenaler Phäochromozytome und deren Metastasen zu. Die Häufigkeit maligner Phäochromozytome schwankt je nach Untersuchung zwischen 10-46\%, wobei die Malignitätsrate der extraadrenalen Tumoren höher ist.

Therapie der Wahl von nicht metastasierten Phäochromozytomen ist die operative Entfernung. Präoperativ erfolgte eine medikamentöse Alphablockade mit Phenoxybenzamin, ggf. müssen perioperativ Betablocker verabreicht werden. Die Entnahme der Tumoren erfolgt in der sog. „No touch“-Technik um eine intraoperative Ausschüttung von Katecholaminen zu verhindern. Die endgültige Diagnose wird nach histologischer Aufarbeitung durch den Pathologen gestellt.

Die vollständige operative Resektion ist derzeit der einzige kurative Therapieansatz. In 25\% der Fälle liegt eine genetische Ursache der Phäochromozytome vor. Hierbei muss insbesondere an die multiple endokrine Neoplasie Typ I (MEN IIa und IIb), die Neurofibromatose Typ I und das von-Hippel-Lindau-Syndrom gedacht werden. Bei unseren Patienten I und III wurde eine Mutation auf dem von-Hippel-Lindau-Gen nachgewiesen. Bei Patient II wurde keine hereditäre Ursache gefunden.

\section{Zusammenfassung}

$\nabla$

Die arterielle Hypertonie mit Tachykardie und Hyperhidrosis sind die Leitsypmtome eines Phäochromozytoms. Die Sonografie ist das bildgebende Verfahren der ersten Wahl. Phäochromozytome sind gut abgrenzbare echoarme Tumore mit einzelnen Zysten, die im Bereich der Nebenniere und des Nierengefäßstiels lokalisiert sind. Als hereditäre Ursache muss eine MEN I, eine Neurofibromatose Typ I sowie das Von-Hippel-Lindau-Syndrom ausgeschlossen werden. metastases. The incidence of malignant pheochromocytoma varies between $10 \%$ and $46 \%$. The rate of malignant tumors is higher when localized in extra-adrenal tissue. Non-metastatic pheochromocytomas are treated by surgical removal. Preoperatively, a drug alpha blockade with phenoxybenzamine should be performed, and beta-blockers should potentially be administered during the surgery. The removal of the tumor is performed in the so-called "no- touch technique" to prevent intraoperative release of catecholamines. The definitive diagnosis is made by histologic processing by the pathologist. Complete surgical resection is currently the only curative therapeutic approach. In $25 \%$ of cases a genetic cause of the pheochromocytoma can be found. Pheochromocytomas may be associated with genetic syndromes such as von Hippel-Lindau disease, as a component of multiple endocrine neoplasia (MEN) syndromes MEN-2A and MEN-2B, and more rarely neurofibromatosis type I. In our patients I and III, a mutation in the von Hippel-Lindau gene was detected. In patient II no hereditary cause was found.

\section{Summary \\ $\nabla$}

The hallmarks of pheochromocytomas are arterial hypertension with tachycardia and hyperhidrosis. Sonography is the first imaging method. Pheochromocytomas are well-defined hypoechoic tumors with single cysts, which are localized in the adrenal gland and along the renal vascular pedicle. Hereditary causes, such as von Hippel-Lindau disease, MEN, neurofibromatosis type I, must be excluded.

\section{Gerdemann, K.-H. Deeg}

Contact: Dr. Christoph Gerdemann christoph.gerdemann@gmx.de 